\title{
Interest Rate and Financial Performance of Banks in Pakistan
}

\author{
Afzal Ahmed \\ Raja $\operatorname{Rehan}^{2}$ \\ Imran Umer Chhapra ${ }^{3}$
}

Saima Supro ${ }^{4}$

\author{
${ }^{, s, 4}$ Shaheed Zulfikar Ali Bhutto Institute \\ of Science \& Technology (SZABIST), \\ Karachi, Pakistan \\ ¿University of Kuala Lumpur, Kuala \\ Lumpur, Malaysia. \\ ${ }^{2}$ Email:rajarehans@hotmail.com
}

Licensed:

This work is licensed under a Creative Commons Attribution 4.0 License.

Keywords:

Interest rate

Profitability

Correlation

Regression

Return on assets

Return on equity

Earnings per share.

JEL Classification:

E4; G2.

\begin{abstract}
The efficiency of banking sector is considered most important for the economic growth, monetary policy implementation and macro-economic stability. The objective of this study is to evaluate the impact of interest rate fluctuations on the profitability of banks. Thus, annual data of seven years from 2007 to 2014 has been taken for 20 banks operating in Pakistan. The sample banks are taken on the basis of highest market share and return. To make substantially noteworthy results study uses Correlation and Regression analysis in order to evaluate the impact of interest rate changes (INT), deposits with other banks (DWOB), advances and loans (ADV) and investment (INV) over the profitability indicators; return on assets (ROA), return on equity ( $R O E$ ) and earnings per share (EPS). The result shows that deposits with other banks and interest rate are negatively affecting the profitability of banks, while advances and loans and investment are having positive influence over profitability of banks.
\end{abstract}

\section{Introduction}

Banking is the most prominent business in this era. Banking system is the vital organ of any economy that facilitates every business. Pakistan's banking sector plays an important role in country's economy since it helps in mobilization of resources, poverty alleviation and controlling public finance. Immediately after Pakistan's inception, banking sector started working and rapid growth was witnessed over the years. Today, the Banking sector of Pakistan continues contributing in the country's economic growth. According to the State Bank of Pakistan Act, the banking system of Pakistan is based on two levels which include the State Bank of Pakistan (SBP), commercial banks, Development Finance Institutions (DFIs), specialized banks, Islamic banks and Microfinance banks. There are 39 commercial banks (including 25 local private banks, 5 public sector commercial banks and 5 foreign banks) and 4 specialized banks. Besides, there are 5 Islamic banks as of Feb 2015.

Pakistani banking industry is flourishing and it has extensive potential of growth. By having a look on the performance and stability indicators there is a noticeable expansion in the profitability of banks. After the large scale growth since 2008, the banking sector of Pakistan encounters certain level of pressures like liquidity and solvency problems which exert significant impact on the performance of banking sector and financial system (Khan \& Sattar, 2014). Due to intense competition, it is largely required of the banks to offer market competitive deposit rates so that they can ensure efficient and effective liquidity management. State Bank of Pakistan has decreased the cash reserve requirement (CRR) and statutory liquidity requirement (SLR) on demand and time liabilities to increase liquidity in market.

The role of state bank of Pakistan (SBP) cannot be ignored in the stability and growth of banking sector because it provides guidelines for efficient and effective working of banks. The effective monetary and transparent fiscal policies are the measures which provide support and stability to the smooth running of banking system. Stable banking system is a sign of stable economy which leads towards saving and investment decision trend, all these measures are vital for the successful operations of the banks. Banks can cover the risk of losses having ability to forecast and risk management techniques. Profit is the most vital thing and also necessity for growth of banking system in financial market. Banks have spread their portfolio assets \& liabilities in a way that influences its profitability, wherever, there is space to improve profitability banks will surely exploit that area for increasing their profit, it shows the importance of financial outcomes for banks. 
Assets of bank are divided into two categories earning assets and non-earning assets: earning assets mean those assets on which the banks earn some sort of profit and they provide the major contribution to the banks' income. In the other hand, non-earning assets serve the purpose of reserve requirements. Thus the earning assets exert significant impact on the banks' profitability.

Interest rate is main tool of monetary policy and an important macroeconomic variable, which is positively linked with country's economic growth. Commonly, interest rate is said to be the cost of capital, means the price paid for money used over a certain time period. (Investopedia.com). Banks as financial intermediary plays a vital role in operations of economic development and its efficiency can also influence the economic advancement. The financial services provided by banks are quite different from other financial institutions and in return bank charges interest. Depositors provide maximum amount of the funds and they receive interest in return. Interest margin is the difference between the interest paid and the interest received.

If banks' interest margin increases they are in benefit but it will have negative impact on the lenders and borrowers. Throughout the last decade increasing trend in interest margin has been observed. Lack of desirable amount of the possible opportunities for financial institutions has further aggravated the impact of spread. Changes in interest rate not only affect the cost of using money (cost of capital) as a result of the decision to invest but also influence the consumption level of an individual. When there is an increase in interest rate it will affect the investment because the cost of capital will increase. On the contrary, when there is decrease in interest rate it will decrease the rates to depositors and suppress the savings. For this reason, serious repercussions are observed on the economy due to the interest rate changes. Unlike other institutions, banks responsiveness to the interest rate changes is quite large. Impact of changes in the interest rate on the profits of banks has remained a momentous issue.

These realities provide an impetus to focus on the current situation of banks profitability. They exert great deal of influence on the efficient and effective handling of banks of their portfolios like assets and liabilities. They also influence the identification of unexplored areas where banks can have possible opportunities to increase their profitability.

Too much fluctuation in interest rate has a great impact on the economy as well as individual and corporate level decision making. The variation of interest rate has immense influence on savings and investments decisions. In the period of 2008-2014 market interest rate in Pakistan has seen an enormous fluctuation which has affected the investments, savings and returns of financial institutions. This is the reason current study evaluates the effect of market interest rate on the financial performance of banks of Pakistan through three independent variables (ROA, ROE and EPS) and four dependent variables (INT, INV, AND \& DWOB) to understand the contribution of such institutions to the financial stability.

\section{Review of Literature}

On the related topic, the numerous studies have been carried out in the past and the focus of those studies was the developing nations. Major purpose of those studies was to discover the factors that influence banks' profitability.

In early literature, for discovering the financial position of the banks, interest rate was used mostly. The net interest margin rate of the banks is extremely delicate to change. The profit of banks increases as the interest rate of the banks increases, according to McCulloch and Shiller (1987) and Samuelson (1945) the general market situation. Samuelson (1945) expressed "The banking system as a whole is immensely assisted rather than hindered by an increase in the interest rate and commercial banks would profit more than savings banks".

The investigation of Maisel and Jacobson (1978) demonstrated that in an efficient market there is no need to consider the institutional forces of market. Financial institution can easily get the outcome from accessible data to foresee the future activities and responses. Financial institutions always discover better approaches to balance their cost and return. They believed that through an efficient financial market they anticipate their asset management results very efficiently and rapidly like cost and return, assets, liabilities. Authors directed this study on the base of cross sections banks cost and revenue from the period 1962-1975. Their estimate was based on cost of book value of assets and the net rate of income. The outcomes additionally demonstrated the major shifting happened in the period of 1970-1975.

The investigation of English (2002) and Hanweck and Ryu (2005) bank's income is largely affected by the changes in the interest rate. As per the investigation of English (2002) the net interest margin of commercial banks and market interest rates revealed steady in the perspective of relationship among the market interest rate and net interest margin of the banks.

The paper of Davies and Vaught (2011) narrated "the impact of interest rate on the profitability of banks in south specific". Findings show that the profit margin of this region banks is in conformity with the line or criteria mentioned by the central banks of all the countries in that specific region. The information was accumulated through the region's central banks prudential. Economic and country risk is comparatively high in this area, the expense of compliance with prudential regulations additionally impact the interest rates, the banks profit remain was high in light of the fact that the ROA is $4.8 \%$ since 2001 , which comes mostly through the foreign exchange dealings of goods and services. 
Research paper of Tahmoorespour and Ardekani (2012) examined the impact of interest rate on the bank return and size of the bank. The data was taken from 14 different markets from the period 2001 to 2010. Researchers considered different financial ratios and bank return as variables for the purpose of study. The analysis shows the different positive and negative results because of fluctuations of interest rate. This is because of difference in market size, macro-economic conditions, monetary policy and difference among countries. Most countries' banks indicated positive associations with return and interest rate difference however couple of countries like India, Japan, Denmark, and Switzerland were not in accordance with it.

Molyneux and Thorton (1992) examined the profitability of banking zone 18 European nations' data amid the 1986-1989 periods, utilizing pooled data. They identified considerable direct relationship with the return on equity and the level of interest rates, bank concentration and government ownership during their study. Their findings recommends that keeping in mind the competition or the quality of bank performance the antitrust or regulatory policy must be formulated according to the changing market structure.

Ogunbiyi and Ihejirika (2014) investigated the effect of interest rates on profitability of deposits money banks in Nigeria. The study covered all the data of thirteen years at the country level and used multivariate regression analysis. The dependent variables for measuring the Banks performance were return on assets (ROA), return on equity (ROE) and net interest margin (NIM). The independent variables were Real interest rate, T-bill rate, Minimum discount rate, interbank rate, Savings deposit rate and Inflation. According to the estimated results, profitability of Nigerian deposits money banks were influenced significantly and negatively by Real interest rate and Savings deposit rate as measured by return on assets and return on equity. In contrast, it was found that there seems to be no prominent relationship between interest rate variables and Net interest margin. According to the results of this study, the profitability of the banking depends on the changing interest rates.

The study of Demirguc-kunt and Huizinga (1999) studied the determinants of the bank profitability and interest rate are: macroeconomic conditions, regulations, organization financial structure, implicit and explicit bank taxation, deposit insurance regulations, bank characteristics and several legal underlying institutional indicators. Study also clarified that foreign banks had higher profit margin in developing countries as compared to domestics banks and a reverse situation is entailing in industrial countries. The regression technique was used to find out the results of determinants on profit and interest rates which were collected from banking institutions of 80 countries from 1988-1995.

Gul studied the relationship between bank-specific and macro-economic characteristics over bank profitability for the period of 2005-2009. Pooled Ordinary Least Square (POLS) method was used to examine the effects. Determinants of banks' profitability were categorized into two types of factors; internal and external factors. The study defined external factors; GDP, Inflation and Market capitalization and internal factors; Size, Capital, Loan, and Deposits as independent variables and return on asset (ROA), return on equity (ROE), return on capital employed (ROCE) and net interest margin (NIM) as the dependent variables. The results showed that the value for R-square in model is 0.54 that shows $54 \%$ of variation in the dependent variable is explained by the independent variable. Overall results found that these bank-specific and macroeconomic factors affect the profitability of banks in Pakistan.

Khan and Sattar (2014) examined the impact of interest rate changes on the profitability of commercial banks operating in Pakistan during 2008-2012. According to study, for the couple of previous years interest rate spread is growing, by which savings and investment are discouraged and on the other hand it ensures the efficient bank lending. For the purpose of discovering the relationship between interest rate and profitability, they used Pearson Correlation method. In their study they took profitability as dependent variable and interest rate as independent variable. They individually analyzed the impact of interest increase and interest decrease on the bank's profitability. The results showed that interest rate and commercial bank's profitability are strongly and negatively correlated. The result differs from the literature review because there is huge banking spread in Pakistan which absorbs the changes in interest rates. In addition, investment also contributes to the banks' earning, so their income does not only depend upon interest margins.

Malik et al. through his study, examined the market interest rate effects on profits of banks. They divided the sample into two categories; the public sector banks and the private sectors banks of Pakistan. Banking lending rate was taken as a proxy for interest rate while return on asset and return on equity were taken as a proxy for profitability. Method of analyses was Regression technique. The results showed that there are significant effects on the profitability of both public sector and private sector, the interest rate affect the private sector the most.

Gull and Zaman (2013) evaluated the impact of interest rate fluctuations and financial outcomes of banking sector of Pakistan. A sample of 20 banks listed at Karachi Stock Exchange KSE - 100 was taken into consideration on the basis of high return and market share for the period of 2007-2012. The determinants for measuring the financial performance were return on assets, return on equity, earnings per share as dependent variables and independent variables include Interest rate, loans or advances, investment and deposits with other banks. Descriptive, correlation and regression analysis were used as statistical techniques. The results showed the value for R-square model for ROA is 0.43 that shows that $43 \%$ variations in ROA is explained by independent variables. The value of $\mathrm{R}$-square for $\mathrm{ROE}$ is 0.30 that shows that $30 \%$ variations in $\mathrm{ROE}$ is 
explained by independent variables. The value of R-square for EPS is 0.717 that shows that $71 \%$ variations in EPS is explained by independent variables. From the Outcomes of analysis it is concluded that interest rate and other variables show significant influence on financial performance of commercial banks operating in Pakistan.

\section{Research Methodology}

To investigate the association between market interest rate and bank's performance in Pakistan, the quantitative approach is used to investigate the variables. All the data is taken from the officials records of the said organizations and at the same interval. The annual data of interest rate is gathered from the reports of State Banks of Pakistan and financial reports of 20 commercial banks are gathered for 2008-2014 from their respective websites. This eight years period is selected due to two reasons. Firstly, during this period of time too much fluctuation was observed in the interest rates and profit margin of banks. Secondly, before 2003 banking sector was using PKRV rate as benchmark rate after that KIBOR rate was introduced as benchmark in banking sector. Selection of these twenty banks is on the premise of high market share and return. Correlation and Multiple Linear Regression analysis is used as statistical techniques.

In light of the objective, the present study tried to test the following hypothesis:

$\mathrm{H}_{1}$ : Interest rate, Advances and Loans, Investments, Deposits with other bank has significant impact on Return on assets of banks of Pakistan.

$\mathrm{H}_{2}$ : Interest rate, rate, Advances and Loans, Investments, Deposits with other bank has significant impact on Return on equity of banks of Pakistan.

$\mathrm{H}_{3}$ : Interest rate, rate, Advances and Loans, Investments, Deposits with other bank has significant impact on Earnings per share of banks of Pakistan.

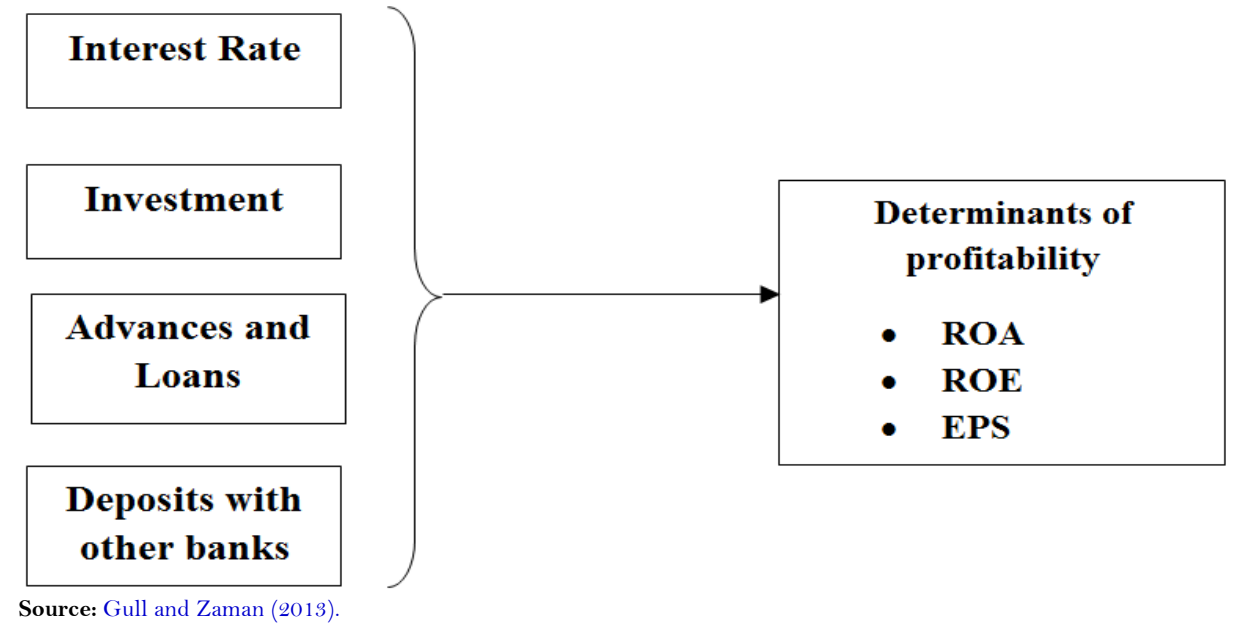

Above figure shows the determinants of profitability comprises of return on assets (ROA), return on equity (ROE) and earnings per share (EPS), which will be the independent variables of this study. While dependent variables are Interest rate (INT), Investment (INV), Advances and loans (ADV) and deposits with other banks (DWOB). This framework was used by Gull and Zaman (2013) in their study of identify the relationship between interest rate changes and financial performance of Pakistani banks. Empirical models that are tested in this paper are:

$\mathrm{ROA}=\beta 0+\beta 1 \mathrm{INT} 1+\beta 2 \mathrm{DWOB} 2+\beta 3 \mathrm{ADV} 3+\beta 4 \mathrm{INV} 4+\mu$

$\mathrm{ROE}=\beta \mathrm{O}+\beta 1 \mathrm{INT} 1+\beta 2 \mathrm{DWOB} 2+\beta 3 \mathrm{ADV} 3+\beta 4 \mathrm{INV} 4+\mu$

$\mathrm{EPS}=\beta 0+\beta 1 \mathrm{INT}_{1}+\beta 2 \mathrm{DWOB} 2+\beta 3 \mathrm{ADV} 3+\beta 4 \mathrm{INV}_{4}+\mu$

4. Analysis and Findings

4.1. Correlation Analysis

Table-1. Correlation Matrix.

\begin{tabular}{l|l|l|l|l}
\hline & ADV & DWOB & INT & INV \\
\hline ADV & 1 & & - & - \\
\hline DWOB & 0.787 & 1 & - & - \\
\hline INT & -0.084 & -0.023 & 1 & - \\
\hline INV & 0.814 & 0.704 & -0.281 & 1 \\
\hline Correlation matrix of independent variables.
\end{tabular}

Correlation matrix of independent variables. 
Table 1 exhibits the results of Correlation analysis. Correlation refers to a relationship used to determine the association and direction of the relationship between two or more variables. The value of correlation coefficient ranges from +1 to -1 . If the value is +1 , this expresses that variables are perfectly positively correlated and move in same direction. If the value is -1 , this suggests that variables are perfectly negatively correlated and move in opposite direction. For the purpose of this study I have analyzed the correlation of independent variables with themselves to find out multi-colinearity among the variables. The advance \& loans is positively associated with DWOB and INV, but negatively associated with INT. Deposits with other banks also have positive relationship with ADV and INV and negatively correlated with INT. Interest is negatively associate with DWOB, ADV and INV. Investment has negative relationship with INT and positive relationship with DWOB and INV. The diagonal value of correlation coefficient is 1 which shows strong and perfect relationship of variable with itself.

\subsection{Statistical Analysis of ROA}

\begin{tabular}{l|l|l|l} 
Table-2. Linear Multiple Regression Analysis. \\
\hline Variables & Coefficients & T-statistic & Significance level \\
\hline (Constant) & .032 & .979 & .329 \\
\hline DWOB & $-4.637 \mathrm{E}-009$ & -1.979 & .000 \\
\hline INV & $4.862 \mathrm{E}-010$ & 4.067 & .000 \\
\hline ADV & $1.185 \mathrm{E}-010$ & 3.535 & .085 \\
\hline INT & -0.039 & -1.735 & .000 \\
\hline R-square 0.582, F-statistic 17.270, Significance value 0.000.
\end{tabular}

The results from Table 2 shows R-square of 0.582 , which imply that $58.20 \%$ of variation in ROA in explained by the independent variables deposits with other banks, investment and interest rate in the model. Furthermore, Table 2 shows F- statistics of 17.270 and significance level is 0.000 which is less than $5 \%$ pvalue so we can conclude that there is significant impact of independent variables on dependent variable. We can reject the null hypothesis.

Deposits with other banks, Interest rate and Investments are found significant having value of 0.000 which is less than the P-value of 0.05 . These variables are significantly influencing the return on assets of banks. While advances is found insignificant having value of significance 0.085 which is greater than p-value 0.05. Deposits with other banks and interest have negative relationship with return on assets of the banks. While advances and investment are positively affecting the return on assets of banks.

\subsection{Statistical Analysis of ROE}

Table-3. Linear Multiple Regression Analysis.

\begin{tabular}{l|l|l|l}
\hline Variables & Coefficients & T-statistic & Significance level \\
\hline (Constant) & -.057 & -.673 & .002 \\
\hline DWOB & $-6.714 \mathrm{E}-009$ & -2.278 & .024 \\
\hline INV & $3.033 \mathrm{E}-010$ & 1.336 & .000 \\
\hline ADV & $8.364 \mathrm{E}-010$ & 4.738 & .000 \\
\hline INT & -.061 & -3.269 & .001 \\
\hline R-square 0.493, F-statistic 10.829, Significance value 0.000. &
\end{tabular}

Table 3 shows R-square of 0.493 , which suggests that $49.30 \%$ of variation in ROE in explained by the independent variables deposits with other banks, advances and loans, investment and interest rate in the model. Table 3 shows F-statistics of 10.829 and significance level is 0.000 which is less than $5 \%$ p-value so we can conclude that there is significant impact of independent variables on dependent variable. We can reject the null hypothesis.

Table also shows the significance of the independent variables which are affecting the dependent variable. Deposits with other banks, interest rate, investments and advances and loans are found significant having value of 0.000 which is less than the $\mathrm{P}$-value of 0.05 . These variables have significant influence on the return on equity of banks. Deposits with other banks and Interest have negative relationship with return on equity of the banks. While advances and investment are positively affecting the return on assets of banks. 


\subsection{Statistical Analysis of EPS}

Table-4. Linear Multiple Regression Analysis.

\begin{tabular}{l|l|l|l}
\hline Variables & Coefficients & T-statistic & Significance level \\
\hline (Constant) & -2.055 & -2.764 & .007 \\
\hline DWOB & $-9.374 \mathrm{E}-008$ & -1.671 & .097 \\
\hline INV & $2.462 \mathrm{E}-008$ & 5.121 & .000 \\
\hline ADV & $1.708 \mathrm{E}-008$ & 3.095 & .002 \\
\hline INT & -0.808 & -1.256 & .001 \\
\hline R-square 0.745, F-statistic 42.150, Significance value 0.000 & &
\end{tabular}

The results from Table 4 shows R-square value of 0.745 , which states that $74.50 \%$ of variation in EPS in explained by the independent variables deposits with other banks, advances and loans, investment and interest rate in the model. F-statistics is 42.150 and significance level is 0.000 which is less than $5 \%$ p-value so we can conclude that there is significant impact of independent variables on dependent variable. We can reject the null hypothesis.

Table 4 shows the significance of the independent variables which are affecting the dependent variable. Interest rate, Advances and loans and Investments are found significant having value of 0.000 which is less than the P-value of 0.05. These variables are significantly influencing the earnings per share of banks. While Deposits with other banks is found insignificant having value of significance 0.097 which is greater than pvalue 0.05. Deposits with other banks and Interest have negative relationship with Return on assets of the banks. While Advances and Investment are positively affecting the return on assets of banks.

\section{Conclusion and Recommendations}

This research is conducted with the objective to examine the relationship between interest rate fluctuation and financial performance of banks. In order to measure the profitability three dependent variables were taken; the return on assets, return on equity and earnings per share. The independent variables were Deposits with other banks, Interest rate, Advances \& loans and Investments. By considering the results of research we can conclude that profitability of banks is significantly affected by changes in the interest rate, deposits with other banks, advances \& loans and investments.

Return on assets is one of the critical factors which help us identify the profitability of banks. As banks increase its deposits with other banks its return on assets decreases because it will decrease the value of total assets. Investments and advances are having positive relationship with return on assets. Increase in investments and advances will increase the bank's assets and it will earn through these investments. Interest rate is having negative relationship with return on assets of banks. If the interest rate decreases people will not keep their money in banks they will seek to hold their money in other investment opportunities. Similarly if interest rates increase people will put their money in banks and earn on their deposits. This will increase the bank's assets and ultimately increase the return on assets of banks.

Another profitability measure in this research was return on equity. Return on equity is having positive relationship with advances and investments. While it has negative relationship with deposits with other banks and interest rate. Earnings per share (EPS) is significantly affected by these variables. Analysis show that advances and investment have strong effect on the earnings per share. On the other hand, deposits with other banks and interest rate are having converse but significant impact on EPS.

The results of this research suggest that banks profitability is an important function of interest rate fluctuation. Through proficient and skillful regulation and administrative structure bank's lending rate polices can be fortified. It's the role of banks' management to manage their portfolios on the basis of long run profitability. Government should also make such monetary policies which will increase the profitability of banks.

This study has only covered the period of 2008 to 2014. Further research can be conducted over a longer timeframe by analyzing the quarterly data. In order to extract more accurate results other econometrics techniques can be run to validate the relationships.

\section{References}

Davies, M., \& Vaught, J. (2011). Interest rates and bank profitability in the South Pacific. Paper Discussed at Forum Economic Ministries Meeting (PETAC Regional Papers).

Demirguc-kunt, A., \& Huizinga, H. (1999). Determinants of commercial bank interest margins and profitability: Some international evidence. The World Bank Economic Review, 13(2), 379-408.

English, W. B. (2002). Interest rate risk and bank net interest margins. BIS Quarterly Review, 1O(1), 67-82.

Gull, A., \& Zaman, A. (2013). Interest rate fluctuations and financial outcomes of banking sector: A case study of Pakistan. International Journal of Research in Commerce \& Management, 4.(7), 125-129.

Hanweck, G., \& Ryu, L. (2005). The sensitivity of bank net interest margins and profitability to credit, interest-rate, and term-tructure shocks across bank product specializations. Working Paper 2005-02. 
Khan, W. A., \& Sattar, A. (2014). Impact of interest rate changes on the profitability of four major commercial banks of Pakistan. International Journal of Accounting and Financial Reporting, 4(1), 142-148.

Maisel, S. J., \& Jacobson, R. (1978). Interest rate changes and commercial banks revenue and cost. Journal of Financial and Quantitative Analysis, 13(4), 678-700.

McCulloch, J. H., \& Shiller, R. J. (1987). The term structure of interest rates: National Bureau of Economic Research.

Molyneux, P., \& Thorton, J. (1992). The determinants of European bank profitability. Journal of Banking and Finance, 16(6), 1173-1178.

Ogunbiyi, S. S., \& Ihejirika, P. (2014). Interest rates and deposit money banks' profitability nexus: The Nigerian experience. Arabian Journal of Business and Management Revierw, 3(11), 133-148.

Samuelson, P. A. (1945). The effect of interest rate increases on the banking system. The American Economic Review, 35(1), $16-27$.

Tahmoorespour, R., \& Ardekani, A. (2012). Examine banks share price sensitivity due to interest rate changes: Emerging markets and advanced countries. Paper Presented at International Conference on Economics, Business Innovation, IPEDR, 3, IACSIT Press, Singapore. pp: 78-82. 